\title{
Miller Fisher syndrome, Bickerstaff brainstem encephalitis and Guillain-Barré syndrome overlap with persistent non- demyelinating conduction blocks: a case report
}

\author{
Angela Puma ${ }^{1,2^{*}}$, Jeanne Benoit ${ }^{1}$, Sabrina Sacconi ${ }^{1,3}$ and Antonino Uncini ${ }^{4}$
}

\begin{abstract}
Background: Miller Fisher syndrome (MFS) and Bickerstaff's Brainstem Encephalitis (BBE) share some clinical features and a common immunological profile characterized by anti-GQ1b antibodies. Some MFS patients overlap with Guillain-Barré syndrome (GBS) or BBE. We report a patient with MFS, BBE, and axonal GBS overlap in whom serial electrophysiological studies showed persistent motor conduction blocks (CBs).

Case presentation: A 61-year-old man acutely developed ophtalmoparesis, ataxia and areflexia suggesting MFS. Paresthesias, severe weakness, and drowsiness rapidly developed indicating an overlap with BBE and GBS. Preceding infection with Mycoplasma Pneumoniae and anti-GQ1b antibodies were detected. On day 4, nerve conduction study showed reduced or non-recordable compound muscle action potentials (CMAPs) and sensory nerve action potentials (SNAPs) without demyelinating features, indicating the electrodiagnosis of acute motor and sensory axonal neuropathy and suggesting a poor prognosis. Intravenous immunoglobulins (IVlg) were given but clinical status worsened to ophthalmoplegia, tetraplegia and coma needing mechanical ventilation. A second IVlg course was given and the patient was weaned off ventilation on day 41 and transferred to rehabilitation on day 57 with partial resolution of the ophthalmoplegia and limited recovery of muscle strength. Electrophysiology showed, after 10 weeks, greatly improved distal CMAP amplitudes suggesting the resolution of distal CBs while CBs in intermediate and proximal nerve segments emerged. CBs unusually persisted for four to 6 months without development of abnormal temporal dispersion. A third IVlg course was started on day 179 and the resolution of CBs mirrored the clinical improvement.
\end{abstract}

Conclusions: GQ1b gangliosides are expressed in the nodal region of oculomotor nerves, muscle spindle afferents, peripheral nerves and possibly in the brainstem reticular formation. Anti-GQ1b antibodies may explain the complex symptomatology and the overlap between MFS, BBE, and GBS.

CBs that persisted and recovered without the development of temporal dispersion suggest that weakness was due to a sustained, antibody-mediated, attack at the nodal region inducing a non-demyelinating conduction failure as expression of an acute onset, long lasting, nodopathy. Serial electrophysiological studies allowed not only to understand the underlying pathophysiology and formulate a more correct prognosis but also to guide the treatment.

Keywords: Guillain-Barré syndrome, Miller Fisher syndrome, Bickerstaff brainstem encephalitis, Anti-GQ1b antibody, Nodopathy, Persistent motor conduction block

\footnotetext{
* Correspondence: puma.ar@chu-nice.fr

'Peripheral Nervous System, Muscle \& ALS Department, University of Nice and Côte d'Azur (UCA), Nice, France

2UMR7370 CNRS, LP2M, Faculté de Médecine, University Côte d'Azur, Nice,

France

Full list of author information is available at the end of the article
}

(c) The Author(s). 2018 Open Access This article is distributed under the terms of the Creative Commons Attribution 4.0 International License (http://creativecommons.org/licenses/by/4.0/), which permits unrestricted use, distribution, and reproduction in any medium, provided you give appropriate credit to the original author(s) and the source, provide a link to the Creative Commons license, and indicate if changes were made. The Creative Commons Public Domain Dedication waiver (http://creativecommons.org/publicdomain/zero/1.0/) applies to the data made available in this article, unless otherwise stated. 


\section{Background}

In the 1950s, Miller Fisher Syndrome (MFS) and Bickerstaff brain encephalitis (BBE) were independently described [1, 2]. Both disorders were related a preceding infection, showed ophthalmoplegia and ataxia, and presented a spontaneous recovery in most cases. MFS patients were areflexic, in keeping with a peripheral nerve etiology, whereas BBE was characterized by altered consciousness and hyperreflexia in some patients, supporting a central pathology. Interestingly, both Fisher and Bickerstaff recognized in the diseases they described similarities with Guillain-Barré syndrome (GBS) $[1,2]$.

In the early 1990s, the discovery of anti-GQ1b IgG antibodies in MFS and BBE provided evidence that both disorders were part of the same disease spectrum, later referred to as anti-GQ1b antibody syndrome [3-5]. MFS patients who develop limb weakness overlapping with Guillain Barré syndrome (GBS), or drowsiness overlapping with BBE $[6,7]$ also support a common immunological profile and clinical spectrum.

We report a patient who developed, after a Mycoplasma Pneumoniae infection, an overlap of MFS, BBE and axonal GBS with GQ1b IgG antibodies and showing, at serial conduction studies, persistent motor conduction blocks (CB).

\section{Case presentation}

A 61-year-old man acutely developed diplopia and balance disorders. $24 \mathrm{~h}$ after onset, he was admitted in the hospital due to ascending paresthesias and an emerging tetraparesis. On day 4 after onset, examination showed a drowsy patient with ophthalmoparesis, areflexia and severe tetraparesis. Plantar responses were flexor. The cerebrospinal fluid study was normal. IgM to Mycoplasma Pneumoniae and IgG anti-GQ1b (1:2560) were detected. IgG and IgM anti- GM1,-GD1a, -GD1b and -GM2 were absent. Two MRIs of the brain, one with gadolinium, were normal. The patient was treated with intravenous immunoglobulin (IVIg) $(0,4 \mathrm{~g} / \mathrm{kg} /$ day $\mathrm{X}$ 5 days) but worsened to complete ophthalmoplegia, tetraplegia and coma needing mechanical ventilation. Considering the severity of the condition a second IVIg course was started on day 24. A few days later he began to improve, with initial resolution of the drowsiness and bulbar symptoms, and partial resolution of the ophtalmoplegia. The patient was weaned off ventilation on day 41 and transferred to rehabilitation on day 57 with improved muscle strength (MCR scale: $2-3 / 5$ in the lower and $2 / 5$ in the upper limbs). After considering the results of the nerve conduction studies performed on days 72 and 128, we searched for antibodies to Neurofascin155, Contactin1 and Contactin associated protein 1 that resulted negative. On the other hand, five months after the onset of symptoms, the anti GQ1b IgG rate remained elevated (1:2560).

A third IVIg course was started on day 179. On day 240 , the patient had recovered muscle strength, except in the right upper limb (MCR scale: 3-4/5) and showed mild gait ataxia.

\section{Nerve conduction studies}

Four serial conduction studies were performed (Table 1, Fig. 1). On day 4 compound muscle action potentials (CMAPs) were not recordable or were very reduced in amplitudes with slightly prolonged distal motor latencies (DML) and normal motor conduction velocities (MCVs). Sensory nerve action potentials (SNAPs) showed reduced amplitudes in the right sural nerve and were not recordable in the five other nerves. On day 72, distal CMAPs, previously undetectable, were measured at 5.3 and $2.6 \mathrm{mV}$ in the median nerves, and $1.1 \mathrm{mV}$ in the left ulnar nerve. CMAP amplitude of the right ulnar nerve was increased by $512 \%$. Partial CBs, defined as $>30 \%$ decrease of proximal CMAP amplitude without abnormal temporal dispersion of proximal CMAP $(<30 \%$ increased CMAP duration) [8], emerged in intermediate nerve segments of both median and ulnar nerves with decrements of proximal CMAP amplitudes ranging from 30.2 to 73\% (Fig. 1). An additional partial CB was detectable in the right median nerve in the Erb's point-axilla segment (Fig. 1). MCVs were slow. SNAPs with reduced amplitude were recordable in $7 / 8$ nerves. On day 128 , distal CMAP amplitudes furtherly increased with however persistently low distal CMAP amplitudes for the common peroneal nerves. Partial CBs improved in the intermediate segments of left median and right ulnar nerves.

The last study on day 240 showed distal CMAP amplitudes in the normal range, except in the left peroneal nerve as well as the resolution of CBs in all nerves with the exception of the emergence of a partial $\mathrm{CB}$ in the intermediate segment of the left peroneal nerve, possibly revealed by the increased distal CMAP amplitude due to the resolution of a distal CB. MCV were still slow in some nerve segments. SNAPs amplitudes remained reduced reaching the normal range in only $1 / 8$ nerves.

\section{Discussion and conclusions}

The patient we describe presented with signs suggesting MFS but rapidly developed impaired consciousness and tetraplegia indicating an overlap with BBE and GBS. IgG anti-GQ1b were detected and serology documented a recent Mycoplasma Pneumoniae infection. MFS overlapping with GBS or BBE has been reported respectively in 15 and $12 \%$ of cases but the triple overlap has rarely been described [6, 7]. Prior Mycoplasma Pneumoniae infection has been reported in GBS, MFS and also in BBE [9]. A common denominator to MFS, BBE and GBS is 
Table 1 Nerve conduction studies

\begin{tabular}{|c|c|c|c|c|c|c|}
\hline Nerve & cMAP $(m V)$ & $\begin{array}{l}\text { Proximal/Distal } \\
\text { CMAP Amplitude (\%) }\end{array}$ & Motor Latencies (ms) & $\begin{array}{l}\text { Proximal/Distal } \\
\text { CMAP Duration (\%)' }\end{array}$ & $\mathrm{CV}(\mathrm{m} / \mathrm{s})$ & $\operatorname{SNAP}(\mu \mathrm{V})$ \\
\hline \multicolumn{7}{|l|}{ Right Median (ABP) } \\
\hline \multicolumn{7}{|l|}{ Day 4} \\
\hline Wrist & NR & NR & NR & NR & NR & \multirow[t]{4}{*}{$N R$} \\
\hline Elbow & NR & $N R$ & $N R$ & $N R$ & NR & \\
\hline Axilla & NR & NR & $N R$ & $N R$ & NR & \\
\hline Erb's Point & NR & & NR & & & \\
\hline \multicolumn{7}{|l|}{ Day 72} \\
\hline Wrist & 5,3 & 69,8 & 3,79 & 73,7 & 31,8 & \multirow[t]{4}{*}{2,1} \\
\hline Elbow & 3,7 & 83,8 & 11,8 & 105,3 & 36,2 & \\
\hline Axilla & 3,1 & 64,5 & 13,6 & 125,4 & 35,2 & \\
\hline Erb's Point & 2 & & 22,4 & & & \\
\hline \multicolumn{7}{|l|}{ Day 128} \\
\hline Wrist & 8,3 & 59 & 4 & 98,4 & 39,3 & \multirow[t]{4}{*}{3,6} \\
\hline Elbow & 4,9 & 93,9 & 11 & 92,3 & 43,8 & \\
\hline Axilla & 4,6 & 54,3 & 12,6 & 120 & 44 & \\
\hline Erb's Point & 2,5 & & 17 & & & \\
\hline \multicolumn{7}{|l|}{ Day 240} \\
\hline Wrist & 8,5 & 91,8 & 3,92 & 100 & 43,2 & \multirow[t]{4}{*}{7,5} \\
\hline Elbow & 7,8 & 97,4 & 10,4 & 104 & 50 & \\
\hline Axilla & 7,6 & 72,3 & 12,2 & 113,7 & 36,2 & \\
\hline Erb's Point & 5,5 & & 18 & & & \\
\hline \multicolumn{7}{|l|}{ Left Median (ABP) } \\
\hline \multicolumn{7}{|l|}{ Day 4} \\
\hline Wrist & NR & NR & NR & NR & NR & \multirow[t]{4}{*}{ NR } \\
\hline Elbow & NR & NR & NR & NR & NR & \\
\hline Axilla & NR & NR & NR & NR & NR & \\
\hline Erb's Point & NR & & NR & & & \\
\hline \multicolumn{7}{|l|}{ Day 72} \\
\hline Wrist & 2,6 & 47,6 & 4,54 & 75,8 & 29,3 & \multirow[t]{3}{*}{ NR } \\
\hline Elbow & 1,24 & 84,7 & 11,5 & 101,4 & 25,6 & \\
\hline Axilla & 1,05 & & 15,2 & & & \\
\hline \multicolumn{7}{|l|}{ Day 128} \\
\hline Wrist & 5 & 62 & 3,26 & 91,3 & 31,2 & \multirow[t]{2}{*}{3,9} \\
\hline Elbow & 3,1 & & $11,6 \mathrm{NR}$ & & & \\
\hline \multicolumn{7}{|l|}{ Day 240} \\
\hline Wrist & 6,2 & 83,8 & 3,26 & 92,1 & 36,6 & \multirow[t]{4}{*}{7,2} \\
\hline Elbow & 5,2 & 100 & 10,5 & 106,8 & 64,3 & \\
\hline Axilla & 5,2 & 92,3 & 11,9 & 109,5 & 41,8 & \\
\hline Erb's Point & 4,8 & & 18 & & & \\
\hline \multicolumn{7}{|l|}{ Right Ulnar (ADM) } \\
\hline \multicolumn{7}{|l|}{ Day 4} \\
\hline Wrist & 0,8 & 75 & 4,1 & 95,3 & 49 & \multirow[t]{2}{*}{ NR } \\
\hline Below Elbow & 0,6 & 100 & 7,8 & 108 & 47 & \\
\hline
\end{tabular}


Table 1 Nerve conduction studies (Continued)

\begin{tabular}{|c|c|c|c|c|c|c|}
\hline Nerve & CMAP $(\mathrm{mV})$ & $\begin{array}{l}\text { Proximal/Distal } \\
\text { CMAP Amplitude (\%) }\end{array}$ & Motor Latencies (ms) & $\begin{array}{l}\text { Proximal/Distal } \\
\text { CMAP Duration (\%)' }\end{array}$ & $\mathrm{CV}(\mathrm{m} / \mathrm{s})$ & $\operatorname{SNAP}(\mu \mathrm{V})$ \\
\hline Above Elbow & 0,6 & 83,3 & 9,5 & 95,5 & 50 & \\
\hline Axilla & 0,5 & & 11,3 & & & \\
\hline \multicolumn{7}{|l|}{ Day 72} \\
\hline Wrist & 4,1 & 27,3 & 3,74 & 128 & 35,6 & 5,2 \\
\hline Below Elbow & 1,12 & 71,4 & 10,9 & 117,8 & 38,2 & \\
\hline Above Elbow & 0,8 & & 13,5 & & & \\
\hline \multicolumn{7}{|l|}{ Day 128} \\
\hline Wrist & 5,7 & 45,6 & 2,3 & 92,2 & 40,1 & 5,4 \\
\hline Below Elbow & 2,6 & 80,8 & 8,54 & 102,8 & 37,6 & \\
\hline Above Elbow & 2,1 & & 11,2 & & & \\
\hline \multicolumn{7}{|l|}{ Day 240} \\
\hline Wrist & 6,8 & 86,7 & 2,03 & 107,7 & 43,8 & 6,7 \\
\hline Below Elbow & 5,9 & 81,3 & 7,63 & 107,1 & 39,3 & \\
\hline Above Elbow & 4,8 & 79,2 & 10,3 & 108,3 & 38,5 & \\
\hline Axilla & 3,8 & & 11,6 & & & \\
\hline \multicolumn{7}{|l|}{ Left Ulnar (ADM) } \\
\hline \multicolumn{7}{|l|}{ Day 4} \\
\hline Wrist & NR & NR & NR & NR & NR & NR \\
\hline Below Elbow & NR & $N R$ & NR & NR & NR & \\
\hline Above Elbow & NR & NR & NR & NR & NR & \\
\hline AXILLA & NR & & NR & & & \\
\hline \multicolumn{7}{|l|}{ Day 72} \\
\hline Wrist & 1,12 & 41,9 & 4,54 & 98,5 & 30,9 & 3,3 \\
\hline Below Elbow & 0,47 & 65,9 & 11,5 & 97 & 32 & \\
\hline Above Elbow & 0,31 & & 15,2 & & & \\
\hline \multicolumn{7}{|l|}{ Day 128} \\
\hline Wrist & 3,1 & 42,2 & 2,75 & 83,5 & 32 & 3 \\
\hline Below Elbow & 1,31 & 91,6 & 9,94 & 100 & 21,5 & \\
\hline Above Elbow & 1,2 & & 11,8 & & & \\
\hline \multicolumn{7}{|l|}{ Day 240} \\
\hline Wrist & 5,1 & 80,3 & 2,89 & 113,3 & 48,4 & 5,7 \\
\hline Below Elbow & 4,1 & 80,5 & 8,06 & 111,8 & 34,7 & \\
\hline Above Elbow & 3,3 & 69,7 & 10,8 & 107 & 47,1 & \\
\hline \multicolumn{7}{|l|}{ Right Peroneal (EDB) } \\
\hline \multicolumn{7}{|l|}{ Day 4} \\
\hline Ankle & 0,9 & 22,2 & 5,9 & 125,2 & 56 & NR \\
\hline Below fibular head & 0,2 & 50 & 11,5 & 83,5 & 46 & \\
\hline Above fibular head & 0,1 & & 13,5 & & & \\
\hline \multicolumn{7}{|l|}{ Day 72} \\
\hline Ankle & 0,75 & 49,3 & 8,13 & 104,4 & 25,3 & 2,1 \\
\hline Below fibular head & 0,37 & 81 & 20,8 & 91,5 & 25 & \\
\hline Above fibular head & 0,3 & & 23 & & & \\
\hline
\end{tabular}


Table 1 Nerve conduction studies (Continued)

\begin{tabular}{|c|c|c|c|c|c|c|}
\hline Nerve & CMAP $(m V)$ & $\begin{array}{l}\text { Proximal/Distal } \\
\text { CMAP Amplitude (\%) }\end{array}$ & Motor Latencies (ms) & $\begin{array}{l}\text { Proximal/Distal } \\
\text { CMAP Duration (\%)' }\end{array}$ & $\mathrm{CV}(\mathrm{m} / \mathrm{s})$ & SNAP $(\mu V)$ \\
\hline \multicolumn{7}{|l|}{ Day 128} \\
\hline Ankle & 0,92 & 71,7 & 4,04 & 97 & 29,4 & 2,7 \\
\hline Below fibular head & 0,66 & 87,9 & 14,6 & 95,3 & 36,1 & \\
\hline Above fibular head & 0,58 & & 16,4 & & & \\
\hline \multicolumn{7}{|l|}{ Day 240} \\
\hline Ankle & 3,3 & 78,7 & 3,9 & 94,2 & 33,3 & 11,6 \\
\hline Below fibular head & 2,6 & 100 & 13,2 & 93,9 & 42,9 & \\
\hline Above fibular head & 2,6 & & 15,3 & & & \\
\hline \multicolumn{7}{|l|}{ Left Peroneal (EDB) } \\
\hline \multicolumn{7}{|l|}{ Day 4} \\
\hline Ankle & $N R$ & NR & $N R$ & $N R$ & $N R$ & $N R$ \\
\hline Below fibular head & $N R$ & NR & $N R$ & $N R$ & NR & \\
\hline Above fibular head & $N R$ & & $N R$ & & & \\
\hline \multicolumn{7}{|l|}{ Day 72} \\
\hline Ankle & $N R$ & NR & NR & NR & NR & 2,6 \\
\hline Below fibular head & $N R$ & NR & NR & $N R$ & NR & \\
\hline Above fibular head & $N R$ & & NR & & & \\
\hline \multicolumn{7}{|l|}{ Day 128} \\
\hline Ankle & 0,24 & 91,6 & 6,35 & 94,6 & 29,8 & 4 \\
\hline Below fibular head & 0,22 & 81,8 & 18,1 & 90 & 32,3 & \\
\hline Above fibular head & 0,18 & & 19,7 & & & \\
\hline \multicolumn{7}{|l|}{ Day 240} \\
\hline Ankle & 1,77 & 61 & 5,34 & 90 & 31,1 & 6,3 \\
\hline Below fibular head & 1,08 & 100 & 15,3 & 104,7 & 34,2 & \\
\hline Above fibular head & 1,08 & & 17,2 & & & \\
\hline \multicolumn{7}{|l|}{ RighT sural } \\
\hline \multicolumn{7}{|l|}{ Day 4} \\
\hline Lateral malleolus & & & & & & 3 \\
\hline \multicolumn{7}{|l|}{ Day 72} \\
\hline Lateral malleolus & & & & & & 3,2 \\
\hline \multicolumn{7}{|l|}{ Day 210} \\
\hline Lateral malleolus & & & & & & 6,6 \\
\hline \multicolumn{7}{|l|}{ Left sural } \\
\hline \multicolumn{7}{|l|}{ Day 4} \\
\hline Lateral malleolus & & & & & & $N R$ \\
\hline \multicolumn{7}{|l|}{ Day 72} \\
\hline Lateral malleolus & & & & & & 3,3 \\
\hline \multicolumn{7}{|l|}{ Day 240} \\
\hline Lateral malleolus & & & & & & 9 \\
\hline
\end{tabular}

Control Values: median nerve: distal CMAP amplitude $\geq 5 \mathrm{mV}, \mathrm{DML} \leq 4 \mathrm{~ms}, \mathrm{MCV} \geq 45 \mathrm{~m} / \mathrm{s} ;$ ulnar nerve: distal CMAP amplitude $\geq 6 \mathrm{mV}, \mathrm{DML} \leq 3,5 \mathrm{~ms}, \mathrm{MCV} \geq 45 \mathrm{~m} / \mathrm{s}$; peroneal nerve: distal CMAP amplitude $\geq 3 \mathrm{mV}, \mathrm{DML} \leq 5,5 \mathrm{~ms}, \mathrm{MCV} \geq 40 \mathrm{~m} / \mathrm{s}$; tibial nerve: distal CMAP amplitude $\geq 5 \mathrm{mV}$, DML $\leq 6 \mathrm{~ms}$. Sensory Action Potential Amplitude: $\geq 10 \mu \mathrm{V}$ for all nerves

Abbreviations: $A P B$ abductor pollicis brevis, $A D M$ abductor digiti minimi, $E D B$ extensor digitorum brevis, $A H$ abductor hallucis, $C M A P$ compound muscle action potential, DML distal motor latency, $C V$ conduction velocity, SNAP sensory nerve action potential, NR not recordable 
the presence of anti-GQ1b antibody [6].GQ1b gangliosides are highly expressed in the nodal and paranodal regions of the oculomotor nerves, muscle spindle afferents, peripheral nerves and possibly in the brainstem reticular formation $[10,11]$. The presence of anti-GQ1b antibodies may explain the complex symptomatology of the patient we report. The overlap among MFS, BBE, and GBS reemphasizes that these disorders are all part of a wide clinical spectrum [12]. The patient presented electrophysiologically with severely reduced or non-recordable CMAPs and SNAPs without demyelinating features indicating, at first test, the electrodiagnosis of acute motor and sensory axonal neuropathy with axonal degeneration and suggesting, in presence of tetraplegia, a poor prognosis. However, distal CMAPs greatly improved in 10 weeks suggesting the resolution of distal CBs whereas CBs in intermediate and proximal nerve segments emerged and unusually persisted for four to 7 months without the development of excessive temporal dispersion of CMAPs, which is considered one of the electrophysiological correlates of de-remyelination [13, 14]. These electrophysiological features and the fact that the resolution of CBs mirrored the clinical improvement suggest that weakness was due to a sustained, antibody-mediated attack at the nodal region inducing a non-demyelinating conduction failure [15-17]. CBs in axonal GBS predominate where the blood-nerve barrier is anatomically deficient, as in the nerve endings, nerve roots, and the common entrapment sites $[15,18]$. We hypothesize that, in the patient we report, the improving of distal conduction blocks revealed already existing proximal conduction blocks that persisted for months [8]. Alternatively, the persistence of the autoimmune attack, supported by the high rate of IgG anti GQ1b 5 months after the onset of symptoms, might have caused the appearance of new CBs in more proximal sites.In this last case, other humoral factors present in our patient's serum probably intervened favoring the disruption of the blood-nerve barrier [19].

Currently, axonal GBS subtypes and MFS are thought to represent acute autoimmune nodopathies with a common pathogenic mechanism characterized by anti-gangliosides mediated dysfunction/disruption of the NAv channel clusters at the Ranvier node and by an electrophysiological continuum from conduction failure, reversible in few weeks, to axonal degeneration [20, 21]. Acute onset and long lasting CBs as in the patient we report, have been described in few patients with IgM antibodies against GM1, GD1a or GD1Q and variably categorized as acute variant
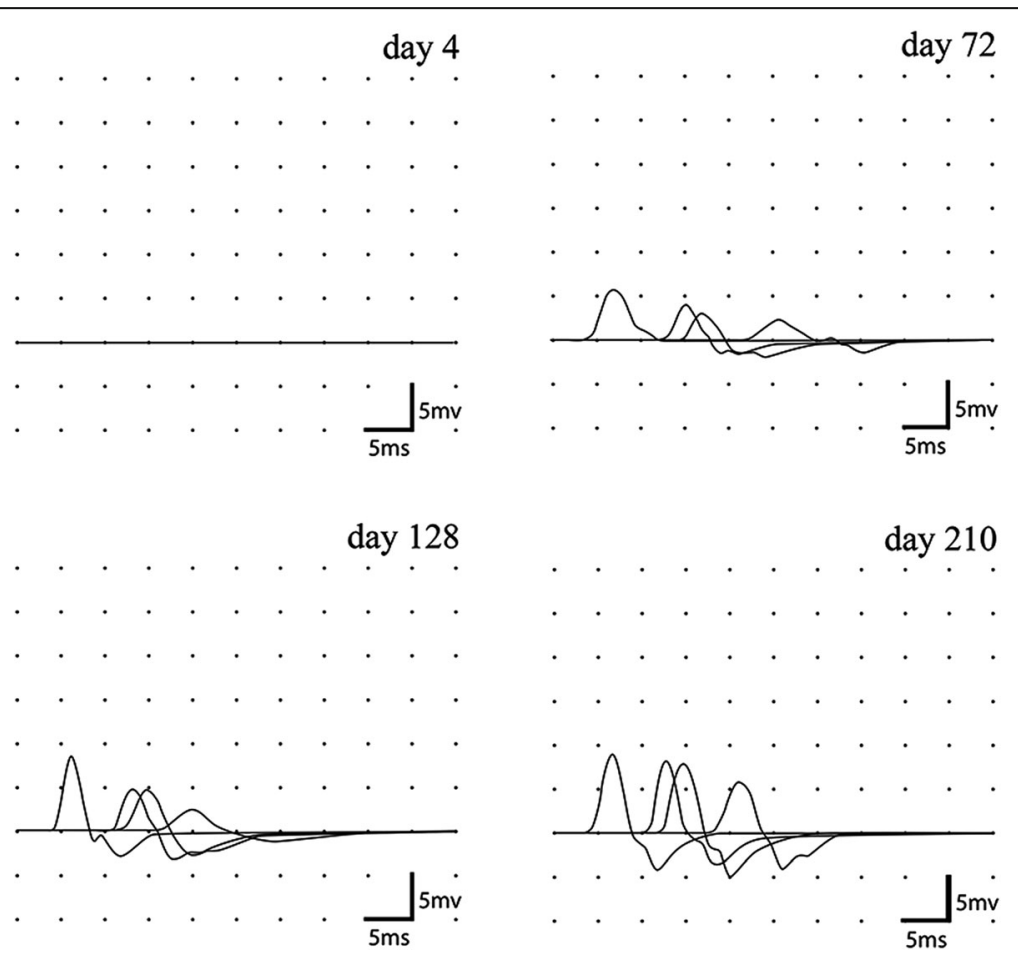

Fig. 1 Serial motor conduction recordings of the right median nerve. Superimposed compound muscle action potentials (CMAPs) recorded from the abductor pollicis brevis after median nerve stimulation at wrist, elbow, axilla and Erb's point. On day 4, distal CMAP was not recordable. On day 72, distal CMAP was 5,3 mV and partial CB was detectable in the elbow-wrist segment (proximal CMAP amplitude reduction $=30,2 \%$; proximal CMAP area reduction $=51,3 \%$ ) and in the Erb's point-axilla segment (proximal CMAP amplitude reduction $=35 \%$; proximal CMAP area reduction $=30 \%$ ). On day 128 distal CMAP amplitude was $8.3 \mathrm{mV}$ but CBs persisted. The last recording on day 210 showed resolution of CBs. In all recordings there was no evidence of CMAP abnormal temporal dispersion 
of multifocal motor neuropathies or chronic forms of acute motor conduction block neuropathies [22-24]. In neuropathies with anti-ganglioside antibodies it is not explained why most patients have an acute onset with conduction failure that may be promptly reversible or progress to axonal degeneration whereas few others are characterized by persistent CBs. In addition to the duration of the immune attack, intrinsic properties of anti-ganglioside antibodies, such as isotype, affinity and capability to activate complement may be implicated.

Notably, except in the first electrophysiological study, the patient showed slowing of nerve conduction that is commonly assumed to be a characteristic of a de-remyelinating process. However, inactivation of Nav channels by intravenous infusion of lidocaine or tetrodotoxin intoxication reduces conduction velocity, even reaching the "demyelinating" range, possibly by increasing the rise time of the action potential and the internodal conduction time $[25,26]$. These findings may well explain the occurrence of slow conduction velocity in an autoimmune neuropathy targeting the excitable axolemma of the node of Ranvier as in the patient we describe [27].

In conclusion, in this patient with an unusual and severe clinical overlap of MFS, BBE, and GBS, serial electrophysiological studies allowed to understand the underlying pathophysiology as attributable to an acute onset, long lasting, nodopathy. Moreover, serial electrophysiology allowed by the second study to formulate a more correct prognosis and guided the treatment as the persistence of CBs encouraged us to carry out a third cycle of IVIg which possibly accelerated the clinical recovery and prevented further axonal degeneration.

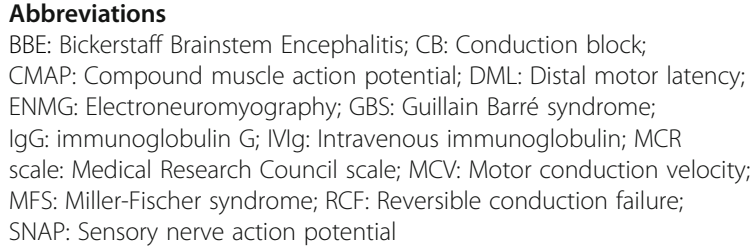

\section{Acknowledgments}

The authors thank Jerome Devaux and Emilien Delmont for antibody assay.

\section{Funding}

None of the authors have received any financial assistance for this manuscript.

\section{Availability of data and materials}

The datasets used and/or analysed during the current study are available from the corresponding author on reasonable request.

\section{Authors' contributions}

AP and AU made the clinical and electrophysiological diagnosis. JB, AP and SS were involved in the direct management of the patient. AP, SS and AU reviewed the literature. JB and AP drafted the first manuscript and AU reviewed all manuscript versions. All authors read and approved the final manuscript.

Ethics approval and consent to participate Not applicable.

\section{Consent for publication}

Written informed consent was obtained from the patient for publication of this case report. A copy of the written consent is available for review by the Editor of this journal.

\section{Competing interests}

The authors declare that they have no competing interests.

\section{Publisher's Note}

Springer Nature remains neutral with regard to jurisdictional claims in published maps and institutional affiliations.

\section{Author details}

${ }^{1}$ Peripheral Nervous System, Muscle \& ALS Department, University of Nice and Côte d'Azur (UCA), Nice, France. ${ }^{2}$ UMR7370 CNRS, LP2M, Faculté de Médecine, University Côte d'Azur, Nice, France. ${ }^{3}$ Université Côte d'Azur, Centre National de la Recherche Scientifique, Institut de Pharmacologie Moléculaire et Cellulaire, Valbonne, France. ${ }^{4}$ Department of Neuroscience, Imaging and Clinical Sciences, University "G. d'Annunzio", Chieti-Pescara, Italy.

Received: 28 April 2018 Accepted: 13 July 2018

Published online: 21 July 2018

\section{References}

1. Fisher M. An unusual variant of acute idiopathic polyneuritis (syndrome of ophthalmoplegia, ataxia and areflexia). N Engl J Med. 1956;255:57-65.

2. Bickerstaff ER. Brain-stem encephalitis; further observations on a grave syndrome with benign prognosis. Br Med J. 1957;1:1384-7.

3. Chiba A, Kusunoki S, Shimizu T, Kanazawa I. Serum IgG antibody to ganglioside GQ1b is a possible marker of miller fisher syndrome. Ann Neurol. 1992;31:677-9.

4. Yuki N, Sato S, Tsuji S, Hozumi I, Miyatake T. An immunologic abnormality common to Bickerstaff's brain stem encephalitis and Fisher's syndrome. J Neurol Sci. 1993;118:83-7.

5. Odaka M, Yuki N, Hirata K. Anti-GQ1b lgG antibody syndrome: clinical and immunological range. J Neurol Neurosurg Psychiatry. 2001;70:50-5.

6. Sekiguchi Y, Mori M, Misawa S, Sawai S, Yuki N, Beppu M, et al. How often and when fisher syndrome is overlapped by Guillain-Barré syndrome or Bickerstaff brainstem encephalitis? Eur J Neurol. 2016;23:1058-63.

7. Pegg EJ, Chhetri SK, Lekwuwa UG, Majeed T. An overlapping case of miller fisher syndrome, Bickerstaff's encephalitis, and the ASMAN variant of Guillain-Barre syndrome. Case Rep Neurol Med. 2016;2016:1596850.

8. Uncini A, Ippoliti L, Shahrizaila N, Sekiguchi Y, Kuwabara S. Optimizing the electrodiagnostic accuracy in Guillain-Barré syndrome subtypes: criteria sets and sparse linear discriminant analysis. Clin Neurophysiol Off J Int Fed Clin Neurophysiol. 2017;128:1176-83.

9. Kuwahara M, Samukawa M, Ikeda T, Morikawa M, Ueno R, Hamada Y, et al, Characterization of the neurological diseases associated with mycoplasma pneumoniae infection and anti-glycolipid antibodies. J Neurol. 2017;264: 467-75

10. Scherer SS. Molecular specializations at nodes and paranodes in peripheral nerve. Microsc Res Tech. 1996;34:452-61.

11. Shahrizaila N, Yuki N. Bickerstaff brainstem encephalitis and fisher syndrome: anti-GQ1b antibody syndrome. J Neurol Neurosurg Psychiatry. 2013;84:57683.

12. Wakerley BR, Uncini A, Yuki N. GBS classification group, GBS classification group. Guillain-Barré and miller fisher syndromes--new diagnostic classification. Nat Rev Neurol. 2014;10:537-44.

13. Uncini A, Manzoli C, Notturno F, Capasso M. Pitfalls in electrodiagnosis of Guillain-Barré syndrome subtypes. J Neurol Neurosurg Psychiatry. 2010;81: 1157-63.

14. Uncini A, Kuwabara S. Electrodiagnostic criteria for Guillain-Barrè syndrome: a critical revision and the need for an update. Clin Neurophysiol Off J Int Fed Clin Neurophysiol. 2012;123:1487-95.

15. Kuwabara S, Yuki N, Koga M, Hattori T, Matsuura D, Miyake M, et al. IgG antiGM1 antibody is associated with reversible conduction failure and axonal degeneration in Guillain-Barré syndrome. Ann Neurol. 1998;44:202-8.

16. Rajabally YA, Hassan-Smith G, Notturno F, Eames PJ, Hayton T, Capasso M, et al. Motor and sensory conduction failure in overlap of Guillain-Barré and miller fisher syndrome: two simultaneous cases. J Neurol Sci. 2011;303:35-8. 
17. Umapathi T, Tan EY, Kokubun N, Verma K, Yuki N. Non-demyelinating, reversible conduction failure in fisher syndrome and related disorders. J Neurol Neurosurg Psychiatry. 2012;83:941-8.

18. Hong Y-H, Sung J-J, Oh M-Y, Moon H-J, Park K-S, Lee K-W. Axonal conduction block at intermediate nerve segments in pure motor GuillainBarré syndrome. J Peripher Nerv Syst JPNS. 2011;16:37-46.

19. Saito K, Shimizu F, Koga M, Sano Y, Tasaki A, Abe M, et al. Blood-brain barrier destruction determines fisher/Bickerstaff clinical phenotypes: an in vitro study. J Neurol Neurosurg Psychiatry. 2013;84:756-65.

20. Uncini A, Susuki K, Yuki N. Nodo-paranodopathy: beyond the demyelinating and axonal classification in anti-ganglioside antibody-mediated neuropathies. Clin Neurophysiol Off J Int Fed Clin Neurophysiol. 2013;124: 1928-34.

21. Uncini A, Kuwabara S. Nodopathies of the peripheral nerve: an emerging concept. J Neurol Neurosurg Psychiatry. 2015;86:1186-95.

22. Lefaucheur J-P, Gregson NA, Gray I, von Raison F, Bertocchi M, Créange A. A variant of multifocal motor neuropathy with acute, generalised presentation and persistent conduction blocks. J Neurol Neurosurg Psychiatry. 2003;74: 1555-61.

23. Manganelli F, Pisciotta C, lodice R, Calandro S, Dubbioso R, Ranieri A, et al. Case of acute motor conduction block neuropathy (AMCBN). Muscle Nerve. 2009:39:224-6

24. Uncini A, Manzoli C, Capasso M. Acute motor conduction block neuropathy or acute multifocal motor neuropathy: an attempt at a nosological systematization. Muscle Nerve. 2010;41:283-5. author reply 285

25. Oda K, Araki K, Totoki T, Shibasaki H. Nerve conduction study of human tetrodotoxication. Neurology. 1989;39:743-5.

26. Yokota T, Saito Y, Miyatake T. Conduction slowing without conduction block of compound muscle and nerve action potentials due to sodium channel block. J Neurol Sci. 1994;124:220-4.

27. Uncini A, Vallat J-M. Autoimmune nodo-paranodopathies of peripheral nerve: the concept is gaining ground. J Neurol Neurosurg Psychiatry. 2018; 89:627-35.

Ready to submit your research? Choose BMC and benefit from:

- fast, convenient online submission

- thorough peer review by experienced researchers in your field

- rapid publication on acceptance

- support for research data, including large and complex data types

- gold Open Access which fosters wider collaboration and increased citations

- maximum visibility for your research: over $100 \mathrm{M}$ website views per year

At $\mathrm{BMC}$, research is always in progress.

Learn more biomedcentral.com/submissions 